\title{
Communication Patterns Used During Learning From Home Mentoring At Kindergarten
}

\author{
Muasisah Jadidah ${ }^{1}$, Eva Riza ${ }^{1}$, Putri Ratih Puspitasari ${ }^{1}$, Sisca Nurul Fadila ${ }^{1}$, Fidesrinur ${ }^{1}$ \\ asis_hasna@yahoo.co.id, evafideza@gmail.com,putri.ratih.puspitasari@gmail.com, \\ kbb.sisca@gmail.com, fidesrinur@gmail.com
}

${ }^{1}$ Mohammad Husni Thamrin University, Al Azhar University Indonesia, Indonesia.

\begin{abstract}
Examining the involvement of parents in finding communication patterns has become very relevant due to the importance of Learning From Home activities. Therefore, this research aims to describe the communication patterns used by teachers and parents in assisting children as well as the aspects that influence the successful implementation of Learning From Home mentoring. This descriptive quantitative research used a population consisting of 6 teachers and 121 parents from the Kramat Jati State Kindergarten, East Jakarta, Indonesia, and employed questionnaires for the data collection. Subsequently, the results revealed several communication patterns between teachers and parents during Learning From Home activities, namely cooperative, interpersonal, transactional, and collaborative. Various influential aspects in successfully implementing this learning process include planning with parents, parental mentoring and guidance, facilities for customer complaints through a Whatsapp group, and motivational aspects provided by parents based on directives from teachers or the school.
\end{abstract}

Keywords: communication patterns, learning from home, State Kindergarten

\section{Introduction}

Several problems surfaced in various sectors, such as health, economy, transportation, and education, due to the Covid-19 pandemic. As a result, kindergarten activities are being conducted via an online system based on Circular Number 04 of 2020 concerning the Implementation of Emergency Policy Education for the Spread of Covid-19 [1]. Data from Indonesia Ministry of Education repository shows that face to face school $(7,1 \%)$, online based learning $(81,7 \%)$ and learning combination $(11,1 \%)$, which used personal/parents funded $(62,2 \%)$ and school funded $(37$, $8 \%$ ) [2]. The research finding shows that problematic situation in conducting online based learning during the covid-19 infrastructure, time management and internet application mastery [3].

Following the absence of face-to-face classroom activities, the learning system in Indonesia changed, with a switch to online through the application of the Learning from Home (LFH) concept. The Ministry of Education and Culture stated that the government decided on applying this concept to all students from Early Childhood Education to tertiary institutions [4]. 
Parents get complaining about learning from home because it needs parents" companion, internet quota, need extra budget [5]. Unfortunately, based on information from kindergarten teacher at Kramat Jati East Jakarta on July $14^{\text {th }} 2021$ by phone found that parents was unable to buy internet quota and to operate smart phone operating wahtsup, video, or google meet where learning from home scheduled from 08:00-09:00 AM and 05:00-08:00 PM according to negotiation between parents and teachers. Hence Covid-19 pandemic decrease educational quality, student lose his opportunity to learn appropriately [6].

Several skills should be possessed by teachers to facilitate online learning, such as 1) the ability to adapt to technology. Their skills should be improved by introducing various applications such as Zoom, Google Meet, alongside the use of audio, visual, and audio-visual systems. 2) Creativity and innovation. This is based on the Circular of the Ministry of Education and Culture No. 4 of 2020 that the target of distance or online learning from home is not curriculum completion. Instead, students are required to produce a lot of work according to the teacher's directives. 3) Effective communication with parents. Having good communication skills is very important in assisting with the growth and development of children during the learning process at home [4].

Hence, the teacher's functions as a facilitator are dominantly replaced by the parents, including in a) preparing children's learning equipment and b) providing explanations and guidance. This condition causes a diversity of children's learning outcomes due to various factors such as the parent's education level and lack of understanding of the teacher's duties, thereby resulting in poorly conveyed materials [7].

The WhatsApp application is one of the most widely used by Early Childhood Education institutions [8]. However, some teachers are still inept at using online-related applications, and many parents are unfamiliar with operating laptops or smartphones [9]. Furthermore, several provisions must be made for teachers to appropriately handle this condition, such as learning plans, enhanced communication, as well as facilities and means to support the online learning implementation during the Covid-19 pandemic [10].

Hence, parents must possess several resources to effectively accompany their children, including 1) an additional burden by providing adequate facilities at their homes, such as mobile phones, laptops, and quotas, to ensure the activities run properly. 2) Additional or extra time. This mentoring is very important to allow the students to understand the material and complete assignments, thereby ensuring the objectives can be achieved according to the teacher's directives. 3) Realize the importance of education and the development of student behavior and skills. This will enable the children to become more creative and develop better due to the consistent participation and adaptation of parents in assisting with the online learning activities [11]. There are five main themes related to parents involvement such as (1) parenting pattern description, (2) communication pattern among parents, teacher and students, (3) parents effort in student's learning assistance, (4) description of parents attitude in decision making, and (5) collaboration among parents, teacher and student [12]. Therefore, based on the various problems described above, this research focuses on the "Communication Patterns used during Learning from Home Mentoring in Kindergarten."

\section{Research Method}


This research employed quantitative-descriptive techniques to obtain an overview of current and past phenomena. The population characteristics comprised parents of kindergarten students, an age range of children between 5-6 years old, housewives as the average parent occupation, with an average educational background of Vocational High School and its equivalents. A total of 121 parents were recorded for this research.
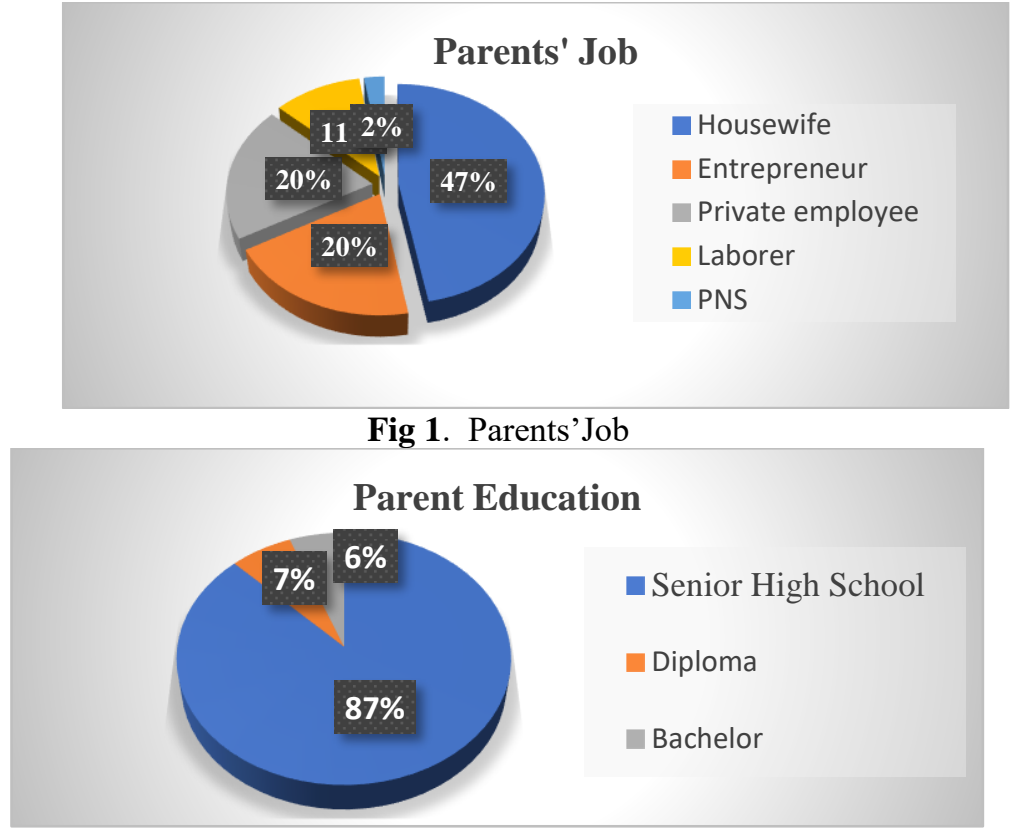

Fig 2. Parent Education

Also, the population included 6 teachers with an average educational background of undergraduate (S1) and a teaching experience of over 5 years. The data collection technique was a closed questionnaire using the Likert interval measurement scale model. Then, descriptive statistical analysis was used to illustrate the communication patterns of parents and teachers in the form of percentage data.

\section{Results And Discussion}

\subsection{Research Result}

The research results are presented in two discussion topics in line with the objectives, namely a description of 1) the communication patterns between parents and teachers and 2) the aspects that influence the successful implementation of the Learning from Home mentoring.

a. Frequency for the Category of Collaborative Communication Patterns between Teachers and Parents 


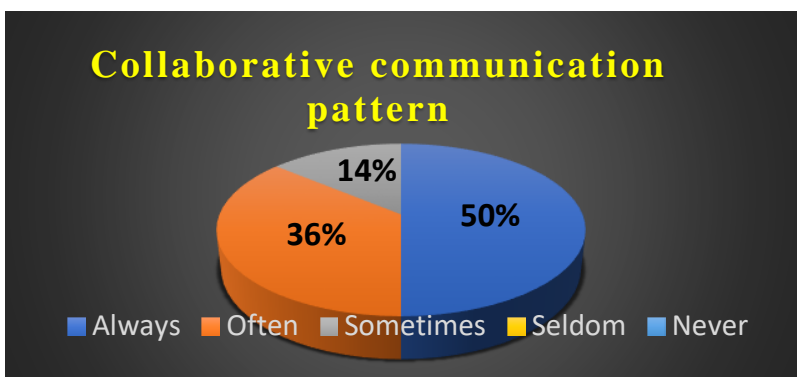

Fig 3. Collaborative Communication

Based on Figure 3, The collaborative communication pattern by category of Always, Often, Sometimes, Seldom, and Never was used by $50.0 \%, 36.1 \%, 13.9 \%, 0 \%$, and $0 \%$, respectively.

b. Frequency for the Category of Transactional Communication Patterns between Teachers and Parents

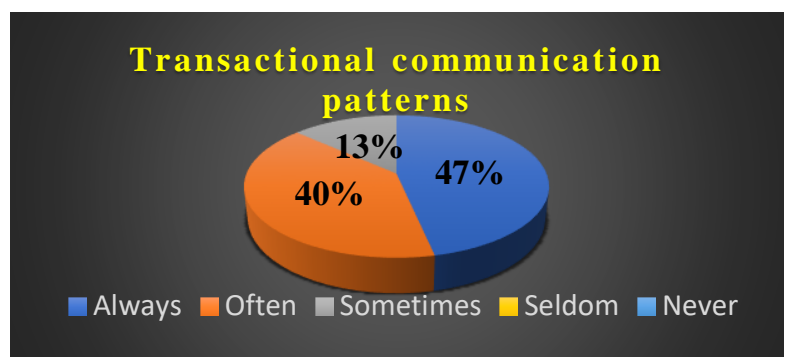

Fig 4. Transactional Communication

Figure 4 shows that the use of the transactional communication pattern according to the categories of Always, Often, Sometimes, Seldom, and Never was 46.6\%, 40.0\%, 13.4\%, 0\%, $0 \%$, respectively.

c. Frequency for the Category of Interpersonal Communication Patterns between Teachers and Parents

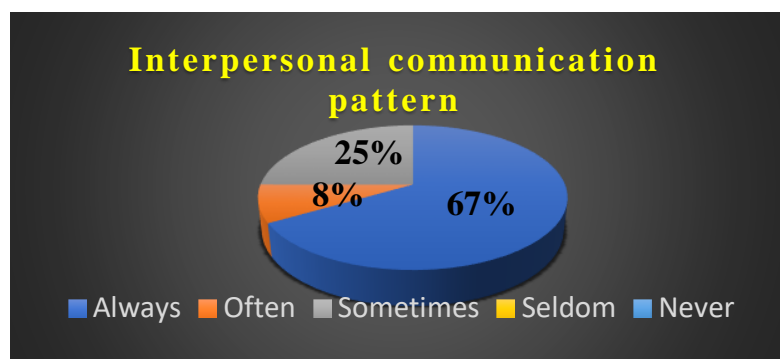

Fig 5. Interpersonal Communication Pattern

According to Figure 5, the average pattern of interpersonal communication in the categories of Always, Often, Sometimes was $66.65 \%, 8.4 \%, 25 \%$, respectively, with Seldom and Never at $0 \%$ each. 
d. Frequency for the Category of Cooperative Communication Patterns between Teachers and Parents

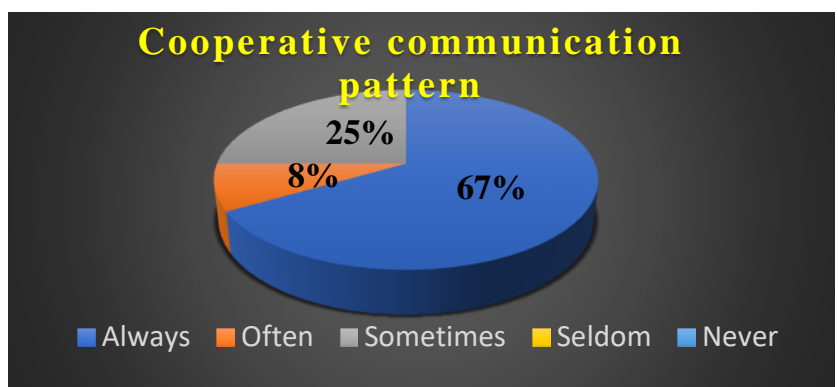

Fig 6. Coorperative Communication Pattern

Based on Figure 6, the cooperative communication pattern to mentor the children was used between teachers and parents Always by 4 participants (66.7\%) as well as Often and Sometimes by 1 person $(16.7 \%$ each).

e. Frequency for the Category of Parental Mentoring and Guidance of Children

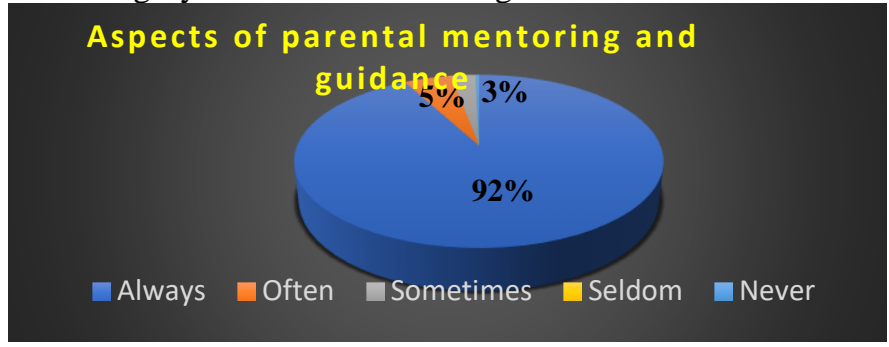

Fig 7. Aspects of Parental Mentoring and Guidance

As shown by Figure 7, the average aspects of parental mentoring and guidance while studying from home were in the categories of Always, Often, Sometimes, Seldom, and Never at $92.15 \%$, $4.95 \%, 2.5 \%, 0 \%$, and $0.4 \%$, respectively.

f. Frequency for the Category of the Learning from Home Implementation Aspect

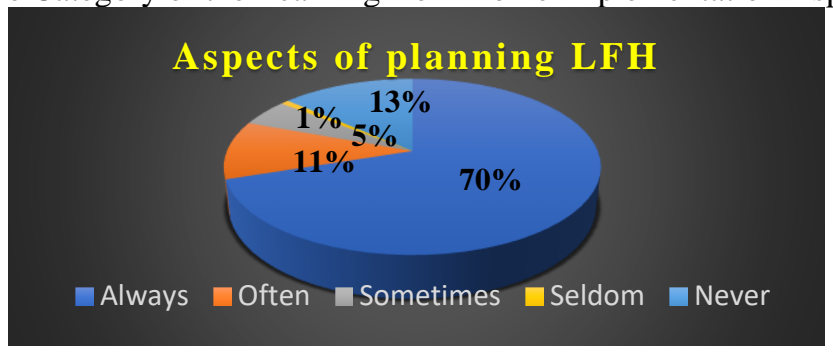

Fig 8. Aspects of Planning LFH

Based on Figure 8, the average learning from home implementation planning involving parents was in the categories of Always, Often, Sometimes, Seldom, and Never, at 69.7\%, 10.7\%, $4.96 \%, 0.83 \%$, and $13.5 \%$, respectively. 
g. Frequency for the Category of Customer Complaints concerning the Learning from Home Implementation

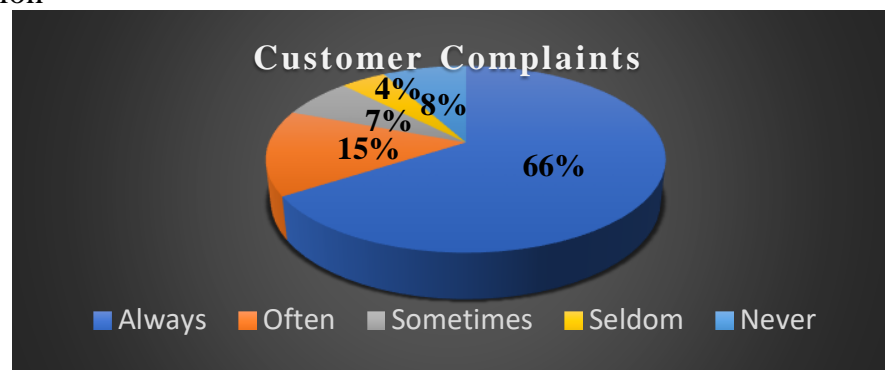

Figure 9. Customer Complaints

Figure 9 illustrates that the average customer complaints concerning the implementation of Learning from Home were Always, Often, Sometimes, Seldom, and Never, at 47.6\%, 10.7\%, $4.96 \%, 3.16 \%$, and $5.8 \%$, respectively.

h. Frequency for the Category of Motivating the Children During the Learning from Home Implementation

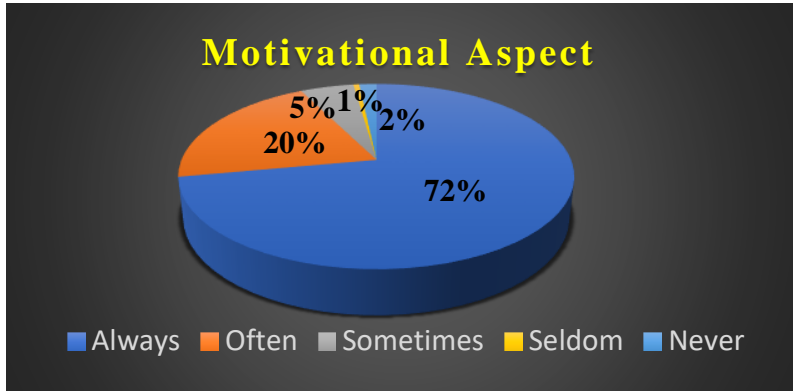

Figure 10. Motivation Aspect

As shown by Figure 10, the children were motivated while learning from home in the categories of Always, Often, Sometimes, Seldom, and Never at $72.4 \%, 20.6 \%, 5.2 \%, 0.56 \%$, and $1.7 \%$, respectively.

i. Frequency for the Category of Learning Outcomes During the Learning from Home Implementation

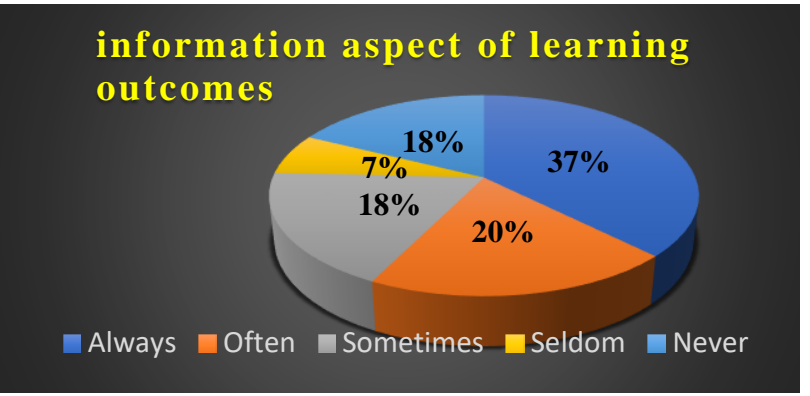

Figure 11. Information Aspect Of Learning Outcomes 
According to Figure 11, information about the children's learning outcomes during Learning from Home were provided Always, Often, Sometimes, Seldom, and Never, at $37.46 \%, 19.8 \%, 18.46 \%, 6.6 \%$, and $18 \%$, respectively

\section{Discussion}

Subsequently, communication between parents and teachers is very influential in the learning from home process. Mutual trust, collaboration in guiding the children, and communication between parents and teachers will offer the children freedom to develop their potential, increase their creativity, and achieve learning success.

Due to the role of the family and teachers are vital in determining students' learning outcomes, good communication between both parties should be established, as it also leads to synergy. Telem \& Pinto proved that communication between parents, teachers, and the community, comprising other family members, school employees, and others, plays an important role in children's academic and social progress [13]. In addition, the synergy between school, home, and parents is very important for children's development, as it creates a more optimal environment where all parties contribute to support this progress [14].

The communication pattern between teachers and parents during the learning from home mentoring process is cooperative, where the teacher or school provides information to parents about the education process. Meanwhile, the interpersonal pattern allows communication with parents, as teachers are confidential about the information conveyed, which makes parents feel safe and comfortable expressing problems or obstacles.

In addition, the school or teacher communicates continuously or transactionally while formulating learning plans, allowing parents to express joy and concern, monitor student attendance, and engage in discussions to improve the learning from home implementation.

The collaborative communication patterns between teachers and parents involve responding and providing feedback, discussing the materials, objectives, and learning outcomes towards a shared vision. This pattern also involves participating in joint decision-making and contributing valuably to maximize student learning and ensure the objectives are achieved.

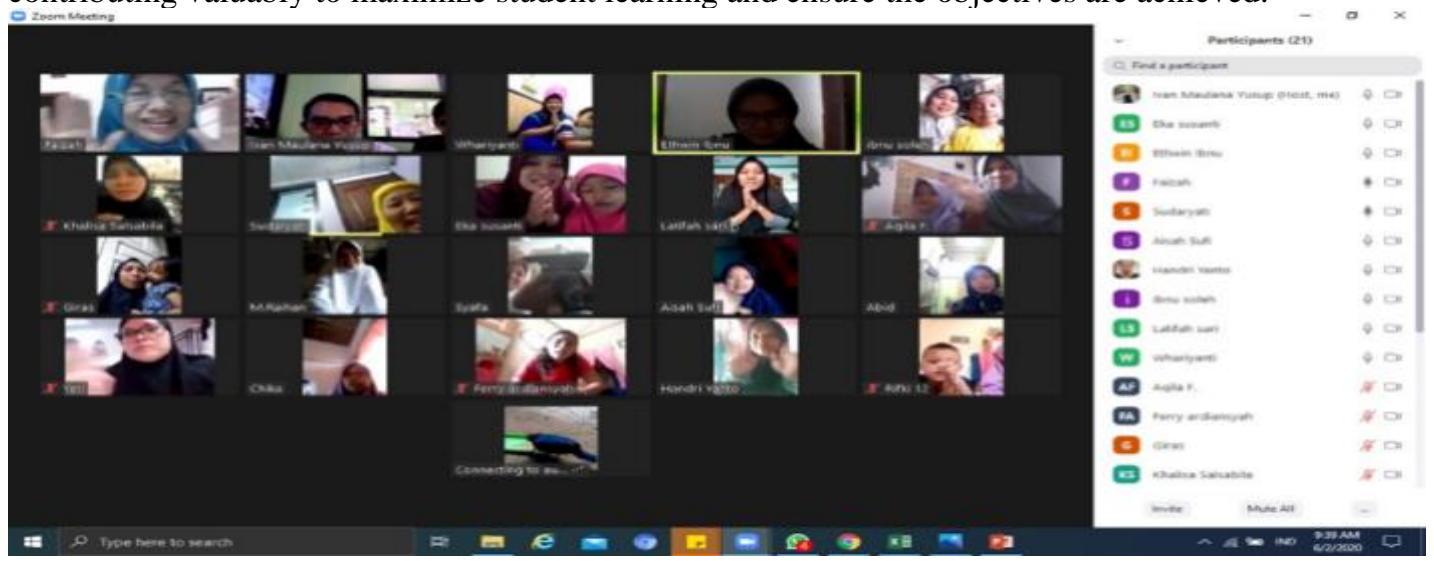

Figure 12. Zoom Meeting between parents and school 
Besides the communication patterns discussed in this research, several aspects were noted to influence the successful implementation of the learning from home activities. For instance, some parents felt excluded from the lesson planning process, particularly those that care, because of the importance of providing input. Meanwhile, the parents agreed that the instructions and learning materials to be taught were shared on the WhatsApp group application.

Furthermore, several aspects influence the successful implementation of the learning from home activities, such as mentoring and guidance from parents, allowing them to contribute to the children's success and achievement. Another important aspect is the problem of customer complaints, particularly the report of problems from the teacher and parents during the learning from the home process. Parents understand the obstacles faced by the teacher, who also accommodates the complaints and problems. Also, they feel the need to be given insight and knowledge about online learning.
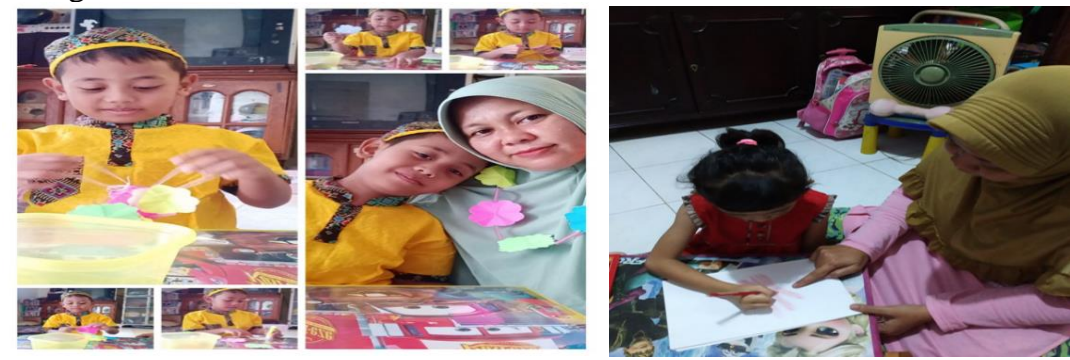

Figure 13. Learning Mentoring by Parents

Motivational is also very significant and involves the provision of information by the teacher on methods to stimulate and encourage children while learning from home. Based on research, parents motivate their children, condition the learning environment comfortably, and monitor the outcomes following information from the school. However, research shows that some parents never make observations and cannot fully monitor the learning activities due to their busy lives.

The existing patterns of interaction and communication have been successful, and both the parents and the school are aware of the activities occurring at home, especially related to learning, interactions with family members, and domestic problems. There is an exchange of information and ideas about the children's development at the school and home. This allows parents to obtain information about their children's actions, while teachers acquire data about their students' activities while playing and learning at home.

According to Epstein in Graham-Clay, communication with parents guarantees their involvement in establishing strong cooperation with teachers [15], and fostering this relationship is considered important in the development of schools as learning communities. Clarke in Minke also stated that a healthy relationship between parents and teachers is characterized by shared beliefs about the importance of the interaction. Also, it is denoted by a mutual commitment to building and maintaining positive relationships with the school, alongside consistency and sustainability in implementing a system that teaches students to behave appropriately [16]. This will foster mutual trust between families and schools, respect for personal rights and obligations, accountability, sensitivity, and understanding. 


\section{Conclusions}

The general results indicate that the several communication patterns between parents and teachers during the learning from home activities are cooperative, interpersonal, transactional, and collaborative.

Furthermore, there are several influential aspects in successfully implementing this learning process, namely good planning, maximum mentoring and guidance from parents, and facilities for customer complaints through the WA group. They also include personal complaints about the problems faced by parents and motivation of the children based on directives from the teacher or the school. Consequently, the existence of good and consistent communication from the parents and the school will build trust in both parties.

Based on the discussion of research results and conclusions, the recommendation below were offered as input for follow-up:

1. The need for parenting activities to develop skills and understanding of the functions of effective communication with children.

2. The need for continuous communication with parents and teachers in schools to optimize learning activities during the pandemic.

3. Further research can explore communication patterns from the child's perspective and study private kindergarten schools with different characteristics from their state counterparts.

\section{Acknowledgments}

The research was funded by the LPPM (Institute for Research and Community Service) Internal Grant, Mohammad Husni Thamrin University, Jakarta.

\section{References}

[1] Circular of the Minister of Education and Culture No. 4 of 2020 concerning the Implementation of Educational Policies in the Emergency Period for the Spread of Corona Virus Disease (COVID-19).

[2] http://repositori.kemdikbud.go.id

[3] Harahap, S. A., Dimyati, D., \& Purwanta, E. (2021). Problematika Pembelajaran Daring dan Luring Anak Usia Dini bagi Guru dan Orang tua di Masa Pandemi Covid 19. Jurnal Obsesi: Jurnal Pendidikan Anak Usia Dini, 5(2), 1825-1836. https://doi.org/10.31004/obsesi.v5i2.1013

[4] Anugrahana, A. (2020). Hambatan, Solusi dan Harapan: Pembelajaran Daring Selama Masa Pandemi Covid-19 Oleh Guru Sekolah Dasar. Scholaria: Jurnal Pendidikan dan Kebudayaan, 10(3), 282-289.

[5] Humaniora, A. I. W. |. (2020). Dampak Pandemi, Kualitas Pendidikan Alami Penurunan. Media Indonesia.

[6] Atikah Ishmah Winahyu. (2020). National Education Consultant in Emergency situation called UNICEF-RDI.

[7] Faizin, F., \& Shafiah, S. (2020). Implementasi Physical Distancing: Pengelolaan Pembelajaran pada Anak Usia Dini melalui Pemanfaatan Perangkat Media Social. Journal of Childhood Education, 4(2), 135-151. 
[8] Nugraheni, A. S. (2020). Metode Pembelajaran Melalui Whatsapp Group Sebagai Antisipasi Penyebaran Covid-19 pada AUD di TK ABA Kleco Kotagede. PAUDIA: Jurnal Penelitian dalam Bidang Pendidikan Anak Usia Dini, 9(1), 126-130.

[9] Nurdin, N., \& Anhusadar, L. (2020). Efektivitas Pembelajaran Online Pendidik PAUD di Tengah Pandemi Covid 19. Jurnal Obsesi: Jurnal Pendidikan Anak Usia Dini, 5(1), 686-697.

[10] Ayuni, D., Marini, T., Fauziddin, M., \& Pahrul, Y. (2020). Kesiapan Guru TK Menghadapi Pembelajaran Daring Masa Pandemi Covid19. Jurnal Obsesi : Jurnal Pendidikan Anak Usia Dini, 5(1), 414.

[11]Agustina, M. R., Dhieni, N., \& Hapidin, H. (2021). Keterlibatan Orang Tua dalam Mendampingi Anak Usia Dini Belajar dari Rumah di Masa Pandemi Covid-19. Jurnal Obsesi: Jurnal Pendidikan Anak Usia Dini, 5(2), 2146-2157. https://doi.org/10.31004/obsesi.v5i2.1160.

[12] Wardhani, T. Z. Y., \& Krisnani, H. (2020). Optimalisasi Peran Pengawasan Orang Tua Dalam Pelaksanaan Sekolah Online Di Masa Pandemi Covid-19. Prosiding Penelitian Dan Pengabdian Kepada Masyarakat, 7(1), 48. https://doi.org/10.24198/jppm.v7i1.28256.

[13] M Telem, and S. Pinto, "Information Technology's Impact on School-Parents and ParentsStudent Interrelations: A Case Study" dalam Palts and Veronika Kalmus. Digital Channels.

[14] J. L. Epstein. "School, Family, and Community Partnerships: Preparing Educators and Improving Schools" dalamPalts, Karmen; and Kalmus, Veronika. (2015). Digital Channels in Teacher-Parent Communication: The Case of Estonia. International Journal of Education and Development using Information and Communication Technology (IJEDICT), 2015, Vol. 11, Issue".

[15] Graham-Clay, Susan. (2005). Communicating With Parents: Strategies For Teachers. School Community Journal, Vol. 16 No. 1 March 2005.

[16] Minke, Kathleen M. (2014). Associations at the within- and between-country level Congruence in Parent -Teacher Relationships. Faculty Publications from CYFS (Children, Youth, Families \& Schools) Nebraska Center for Research, University of Nebraska - Lincoln.

[17] Sukmadinata, N.S. (2011). Metode penelitian pendidikan. Cetakan ke 7. Bandung: Remaja Rosdakarya 